\title{
Promotion of Political Values through International Programs of Academic Mobility
}

\author{
De Martino Mario \\ Peoples' Friendship University of Russia (RUDN University) \\ 6 Miklukho-Maklaya St, Moscow, 117198, Russian Federation \\ de-martino-m@rudn.ru
}

\section{Продвижение политических ценностей посредством международных программ академической мобильности}

\author{
Де Мартино Марио \\ Российский университет дружбы народов \\ Российская Федерация, 117198, Москва, ул. Миклухо-Маклая, 6 \\ de-martino-m@rudn.ru
}

\begin{abstract}
Nation-states and international organizations widely use educational programs to foster students' mobility abroad. The majority of scientific literature agrees in considering exchange programs as soft power instruments used by countries to promote their values in geopolitically and economically crucial regions. However, a more in-depth analysis of the reasons motivating nation-states to adopt such initiatives is needed to understand their political goals better. The current study consists of analysing the main formulations proposed by scholars, who delved into the topic of international academic mobility as a tool to promote values. The rationales of nation-states and international organizations to develop such programs of academic mobility can be very diverse (geopolitical, economic, and civic). The author described the main principles of each rationale (or logic), providing examples of existing educational programs adopted by countries or international organizations and how political values are promoted according to each logic. The boundaries between the four rationales described in the paper are not distinct and rigid. An educational program can respond at the same time to different logics, and the nation-states decide how to allocate resources to achieve specific results ascribable to a particular rationale. Although different rationales push nation-states and international organizations in promoting international programs of academic mobility, in all cases, such programs are instruments to promote political values.
\end{abstract}

Keywords: Political values, Educational policy, international educational programs, Nationstate, Fulbright program, Erasmus program, European Union

(C) De Martino M., 2020.

(c) (i) This work is licensed under a Creative Commons Attribution 4.0 International License https://creativecommons.org/licenses/by/4.0/ 
Article history: Submitted on 29.02.2020. Accepted on 10.03.2020.

For citation: De Martino M. Promotion of Political Values through International Programs of Academic Mobility. RUDN Journal of Political Science. 2020; 22 (2): 312-319. DOI: 10.22363/ 2313-1438-2020-22-2-312-319

Аннотация. Национальные государства и международные организации широко используют образовательные программы для развития мобильности студентов за рубежом. В научной литературе большинство авторов сходятся во мнении, что такие обменные программы являются инструментами мягкой силы, используемыми странами для продвижения своих ценностей в геополитически и экономически важных регионах. Однако более глубокий анализ причин, побуждающих национальные государства использовать подобные инициативы, требует лучшего понимания их политических целей. Настоящее исследование состоит из анализа основных понятий, предложенных учеными, которые подробно изучили тему международной академической мобильности как инструмента продвижения ценностей. Национальные государства и международные организации используют различные обоснования для разработки таких программ академической мобильности (геополитические, экономические, гражданские и модель лидера мнений). Автор описывает основные принципы каждого из подходов, приведя примеры существующих образовательных программ, принятых странами или международными организациями, а также ответил на вопрос, каким образом политические ценности продвигаются, согласно каждому подходу. Границы между четырьмя обоснованиями, описанными в статье, не жестко фиксированы. Образовательная программа может одновременно отвечать различным логическим схемам, а национальные государства решают, как распределить ресурсы для достижения конкретных результатов, в рамках конкретного обоснования. Хотя различные обоснования стимулируют национальные государства и международные организации на продвижение международных программ академической мобильности, во всех случаях такие программы выступают в качестве инструментов продвижения политических ценностей.

Ключевые слова: Политические ценности, образовательная политика, международные образовательные программы, национальное государство, программа Фулбрайт, программа Erasmus, Европейский Союз

История статьи: Поступила в редакцию 29.02.2020. Принята к публикации 10.03.2020.

Для цитирования: De Martino M. Promotion of Political Values Through International Programs of Academic Mobility // Вестник Российского университета дружбы народов. Серия: Политология. 2020. Т. 22. № 2. С. 312-319. DOI: 10.22363/2313-1438-2020-22-2-312-319

\section{Introduction}

Education is a sharp instrument that nations can use to promote political values such as human dignity and human rights, freedom, democracy, equality, and the rule of law. For instance, during the cold war, the United States and the Soviet Union used scholarship schemes to attract students of other countries to educate them in several fields and, at the same time, transmit them their culture and values. This practice is not new, and it is possible to find other examples in the past before the Cold War. It is the case of the colonial period, when European powers organized the entire educational systems in colonized countries, imposing their values, culture, and language to them [1]. Nation-states can transmit values 
through a public diplomacy strategy, so peacefully, or adopting a more coercive approach as during the colonial period.

What are the reasons pushing states to allocate their financial and human resources to develop international programs addressed to citizens of other nations?

From the scientific literature, which has widely studied such phenomenon, it is possible to identify four main rationales explaining it:

1. Geopolitical rationale;

2. Economic rationale;

3. Civic rationale.

\section{Geopolitical rationale}

Education can be an instrument to maintain or extend the influence of a country in other regions of the world. The USA and USSR followed this logic during the Cold War when they widely used education to consolidate their control to affiliated or neutral areas of the globe to promote their ideologies. A typical example from the side of the USA is the Fulbright program, which enabled the hundred of thousands of technical trainees and students from many regions of the world to carry out part of their education in the United States. Several authors underlined how such a program promoted the spread of democratic ideals and American values abroad [2]. Also, the Soviet Union adopted similar instruments, and Peoples' Friendship University Patrice Lumumba, a university opened in 1960 to educate people from affiliated countries of the USSR, is considered one of the primary examples of Soviet cultural policy during the Cold War [3].

The geopolitical or national security rationale is not a widespread practice only of the past. Nowadays, for instance, several countries such as Russia or Turkey and international organizations such as the European Union use educational programs to strengthen links with certain countries through education. Some examples are the CIS University network, used by Russia to strengthen the ties with former Soviet countries [4], and the Turkish cultural diplomacy oriented to enhance the collaboration with neighbour countries in the Balkans and the Middle East to reinforce its position in the region [5]. The technical assistance program in the field of higher education TEMPUS launched by the European Communities in 1990 was a response to the fall of the Berlin wall. It supported a smooth transition to the market economy and democracy in Central and Eastern European countries with the perspective of their future joining in the EU [6].

A sub-category of the geopolitical rationale is the opinion leader model, which combines political and psychological considerations in assessing the impact of academic exchanges abroad. According to this perspective, in case of success, the experience of study abroad can contribute not only to the personal development of the beneficiary of the scholarship, but also a further leadership potential and further encouragement of ambition. This school of thought supports the idea that international programs of academic mobility can even shape international relations because the beneficiaries of the scholarships after the completion of their 
studies can achieve critical positions of leadership in their countries. During their stay abroad, international students familiarize themselves with the host country and often adopt a positive attitude towards it. After the mobility period, when the graduates grow up professionally, they cultivate friendly relations towards the host country, sponsoring and mobilizing others to the same end.

In the 1940s, American communications researchers formulated the concept of 'opinion leader' based on the idea that recognized knowledge obtained from direct experience could work as catalyzers and transmitters of information within a given community. The United States used academic exchanges intending to reeducate German society towards democratic principles in post-war Germany. The studies of these mobility programs demonstrated that the 'opinion leader' model reached the expected results since the participants in exchange programs acted freely as respected and legitimate sources of judgment and option on the US [7].

With the technological revolution in the last few years, where news circulates faster, and it is easier to access, exchange programs have lost part of their vigour in functioning as broadcasters of information to wider communities. However, the human factor persists a crucial factor in the academic exchanges abroad, and we should not underestimate how vital are personal contacts and the ongoing influence of direct experience [8].

In the geopolitical perspective, depending on the goal desired and the resources available, nation-states and international organizations can adopt diverse approaches in promoting political values through educational programs to targeted regions. They can use a top-down approach, involving in the educational programs more talented students with the aim that after the studies, once the beneficiary will take a leadership role in the home country, he or she will promote such values to the rest of the population. We can associate this case to the opinion leader model abovementioned. In this regard, the American political scientist Joseph Nye gives an excellent example in his work "Soft Power The Means to Success in World Politics". In his book, Nye reports that the Soviet politician Aleksandr Yakovlev studied in the 50s in the United States. Such experience influenced him to the point that thirty years later, when he became a Politburo member, he had a considerable influence in promoting liberal reforms during Mikhail Gorbachev's presidency [9]. Alternatively, nation-states and international organizations can use a bottom-up approach. In such a case, educational programs embrace a broader target group, including organizations such as universities, NGOs, civil society, etc. In the bottom-up approach, the target group benefits directly from international educational programs taking part in them. After educational activities, the direct beneficiaries of such programs may act as a catalyzer of political values to the rest of society, reaching decision-makers and influencing them in their policies.

\section{Economic rationale}

According to this logic, nations rely on international educational programs to obtain some profits. The economic benefits can be of different types. Some coun- 
tries and universities generate a considerable portion of their incomes, thanks to the tuition fees of international students. A certain number of nation-states, like the United States, Great Britain, Canada, and Australia, with a commercialised full-fee approach and are leading exporters of education services in the world, generating for them a considerable portion of their GDP [10]. According to the data published by Universities U.K., the advocacy organisation for universities in the United Kingdom, international students coming to the U.K. provides a significant boost to local businesses and regional jobs. Besides, they injected more than $£ 25$ billion a year into the British economy [11]. Also, the organization Universities Australia underlined that international students generated $\$ 32$ billion for the Australian economy, boosting wages and jobs in the financial year 2018 [12].

At the same time, in other cases, foreign graduates become inbound highqualified workers when they decide to remain in the host country after the completion of their studies [13]. Such a phenomenon, commonly defined as 'brain drain', is widely debated by scholars. If, on the one hand, it can create some economic benefits from the host country, on the other hand, it creates a loss of human capital for the home country, which can only be compensated by the remittances from the high-skilled migrants [14]. According to the international nonprofit association NAFSA (Association of International Educators), during the 2018-2019 academic year, international students studying in the US brought almost $\$ 41$ billion, and they supported 458,290 jobs in the United States [15]. These data confirm that international students represent a valuable source of income for the host country.

Vassiliki Papatsiba, senior lecturer of the School of Education at the University of Sheffield, underlines that the educational program Erasmus in Europe has not only an impact on European higher education but also at economic level in the achievement of the European Single Market [16]. The European integration process started as a project of European nations focused on commercial matters, and gradually, it embraced other sectors, including education. The achievement of a European Single Market, which implied the free circulation of people, goods, capital, and services, could not ignore issues related to education. In other words, a European worker moving from an EU country to another, should not face restrictions associated with the recognition of diploma obtained in another European country. Also, the free circulation of students in Europe thanks to the Erasmus program, enable them to enhance their competences and skills, which have a positive effect on the national and whole European economy.

In the economic rationale, the promotion of political values through international education programs is indirect. The first objective is to obtain some profits, then popularize specific values as freedom, democracy, equality, and the rule of law, and economic pragmatism. For instance, in the case mentioned above of the European Union, the economic benefits can be for all the actors involved. Nation-states will obtain benefits in having more skilled workers and upgrade of some sectors of their economy, workers will become higher qualified and betterremunerated, and the EU will have a more technologically advanced and integrated Single Market. The economic success can have a spillover effect and facilitate among the society the appreciation of values like the freedom to con- 
duct business, which encourages innovation, entrepreneurship, economic, and social development.

\section{Civic rationale}

International programs of academic mobility are a vital tool to improve life in society at large and relations among citizens. Educational programs, according to the civic rationale, can help in "creating a better world community" through "investing in people" [17]. In other words, international programs of academic mobility can help individuals to understand better societies of other nations, promoting peaceful collaboration between countries.

Within such a rationale, it is possible to identify some sub-categories. A part of the scientific literature stresses the benefits that international educational programs can generate on their participants for their personal development. Some of the primary skills and competencies, which several author stress are: enhanced language skills, more self-confidence, changes in attitudes and career goals, more solidarity, increased knowledge concerning international affairs [17, 18].

Another part of the scientific literature, narrowing the analysis on personal development with a focus on the European integration process, stresses that the international programs of academic mobility, and in particular the Erasmus program, is a tool to develop a European identity [16, 19, 20]. According to such perspective, the cultural and social aspects of students' mobility are crucial elements contributing to creating European citizens. In this logic, the concepts of a "Europe of knowledge" and "People's Europe" are closely interconnected. Since the beginning of the Erasmus program in 1989, the European Commission stressed that the creation of a European dimension of education is a crucial element to strengthen the European citizenship and identity. The scholar Isabel Petit affirms that the European Commission hoped to promote an EU identity through its education policy, which the founding fathers considered necessary to achieve "an ever closer union" [19].

In the civic rationale logic, the promotion of political values through international educational programs may have a positive impact on society at large. For instance, in the case of the European Union, there is a part of academia that embraces the idea that the Erasmus program contributes to promoting values such as tolerance, democracy, freedom, and at a further stage, a sense of European identity $[21,22]$. From the civic rationale perspective, the international programs of academic mobility play a crucial role in spreading political values building a society more inclined in principles considered fundamentals for the community in its entirety.

\section{Conclusive remarks}

The reasons pushing states to promote international programs of academic mobility, as we have seen, are very diverse. However, the boundaries between each rationale described in the previous paragraphs are not distinct and rigid. In other words, we can associate an educational program with different grounds at 
the same time. For instance, the Erasmus program embodies at the same time an economic logic (contribute to achieving a European Single Market) and a civic rationale (creation of a European demos and identity). Also, the Fulbright program responds to multiple grounds. On the one hand, it contributes to consolidating the sphere of influence of the United States globally (geopolitical rationale); on the other hand, it attracts talented students deciding in some instances to continue their academic or professional career in the US (economic logic). Also, the Fulbright program supports the education and training of future leaders of other nations so that we can associate with it the opinion leader model as well.

In designing such programs, decision-makers decide how to allocate resources to achieve specific results ascribable to a particular rationale. For instance, when the European Union elaborates educational programs before the beginning of each financial period, it decides how many resources allocate to intra-European mobility and how many to extra-European mobility. This difference is essential because while mobility between European countries contributes to strengthening the links between EU member states (economic rationale and civic rationale), mobility between European and third countries reinforces the role of the EU as a regional and global actor (geopolitical logic).

Although different rationales push nation-states and international organizations in promoting international programs of academic mobility, in all cases, such programs are instruments to promote political values. Both countries and international organizations decide which rationale fits better in their political agenda and design academic programs addressed to citizens of other countries to maximize the expected benefits.

\section{References}

[1] Scott P. Globalisation and higher education: Challenges for the 21st century. Journal of Studies in International Education, 2000, 4.1: 3-10: 5.

[2] Spilimbergo A. Democracy and foreign education. American economic review, 2009, 99.1: 528-43; Fonte R. Higher education in service to democracy. Community College Journal, 2009, 79.5: 44.

[3] Katsakioris C. The Lumumba University in Moscow: higher education for a Soviet-Third World alliance, 1960-91. Journal of Global History, 2019, 14.2: 281-300; Lebovic S. From War Junk to Educational Exchange: The World War II Origins of the Fulbright Program and the Foundations of American Cultural Globalism, 1945-1950. Diplomatic History, 2013, 37.2: $280-312$.

[4] Jokisipilä M. East or West-or both at the same time?: Higher education as a battleground for the Russian soul. The Baltic Sea region, 2014, 12: 375-399.

[5] Donelli F. Persuading through Culture, Values, and Ideas. Insight Turkey, 2019, 21.3: 113134.

[6] Mccabe R., Ruffio P., Heinämäki P. Tempus@ 20: A Retrospective of the Tempus Programme Over the Past Twenty Years (1990-2010). EUR-OP, 2011.

[7] Scott-Smith G. Exchange programs and public diplomacy. Routledge handbook of public diplomacy. Routledge, 2020: 38-49.

[8] Scott-Smith G. Mapping the undefinable: Some thoughts on the relevance of exchange programs within international relations theory. The Annals of the American Academy of Political and Social Science, 2008, 616.1: 173-195. 
[9] NYE, Joseph. Soft Power: Means to Success in World Politics. New York: Public Affairs, 2004. $191 \mathrm{p}$.

[10] Altbach P.G., Knight J. The internationalization of higher education: Motivations and realities. Journal of studies in international education, 2007, 11.3-4: 290-305.

[11] Universities U.K., International students now worth $£ 25$ billion to U.K. economy - new research, URL: https://www.universitiesuk.ac.uk/news/Pages/International-students-nowworth-25-billion-to-UK-economy---new-research.aspx. Accessed: 05.03.2020.

[12] Universities Australia, International students inject \$32 billion a year into Australia's economy - boosting Aussie jobs and wages. URL: https://www.universitiesaustralia.edu.au/ media-item/international-students-inject-32-billion-a-year-into-australias-economy-boosting-aussiejobs-and-wages/. Accessed: 05.03.2020.

[13] Finn M.G. Stay rates of foreign doctorate recipients from US universities, 2007. Oak Ridge Inst. for Science and Education (ORISE), Oak Ridge, TN (United States), 2010.

[14] Boeri T., et al. Brain drain and brain gain the global competition to attract high-skilled migrants. 2012.

[15] NAFSA, The United States of America: Benefits from International Students https://www.nafsa.org/sites/default/files/media/document/isev-2019.pdf (webpage consulted on 05/03/2020).

[16] Papatsiba V. Political and Individual Rationales of Student Mobility: a case-study of ERASMUS and a French regional scheme for studies abroad. European journal of education, 2005, 40.2: 173-188.

[17] Sowa P.A. How valuable are student exchange programs? New Directions for Higher Education, 2002: 63-70.

[18] Marciniak D., Winnicki M. International student exchange-motives, benefits and barriers of participation. Zeszyty Naukowe. Organizacja i Zarządzanie/Politechnika Śląska, 2019, 133 Management in Industry and Services: 93-105.

[19] Petit I. Mimicking history: The European Commission and its education policy. World Political Science, 2007, 3.1.

[20] Mitchell K. Rethinking the "Erasmus Effect" on European Identity. JCMS: Journal of Common Market Studies, 2015, 53.2: 330-348.

[21] KING, Russell; RUIZ-GELICES, Enric. International student migration and the European' year abroad': effects on European identity and subsequent migration behaviour. International Journal of Population Geography, 2003, 9.3: 229-252.

[22] VAN MOL, Christof. The influence of European student mobility on European indentity and subsequent migration behaviour. In: Analysing the consequences of academic mobility and migration/Dervin, Fred [edit.]. 2011: 29-50.

\section{Информация об авторе:}

Де Мартино Марио - кандидат политических наук, Заместитель начальника отдела взаимодействия с международными организациями Департамента по международному научнообразовательному сотрудничеству Российского университета дружбы народов (ORCID ID: 0000-0002-3903-6532) (e-mail: de-martino-m@rudn.ru).

\section{Information about the author:}

Mario De Martino - PhD in Political Sciences, Deputy Head of the Department for Interaction with International Organizations of the Department for International Scientific and Educational Cooperation, Peoples' Friendship University of Russia (RUDN University) (Russian Federation) (ORCID ID: 0000-0002-3903-6532) (e-mail: de-martino-m@rudn.ru). 